Western University Scholarship@Western

Law Publications

Law School

2002

\title{
Implementing the Information Rights of Canadian Children
}

Margaret Ann Wilkinson

Western University,mawilk@uwo.ca

Lynne EF McKechnie

Follow this and additional works at: https://ir.lib.uwo.ca/lawpub

Part of the Law Commons

Citation of this paper:

Wilkinson, Margaret Ann and McKechnie, Lynne EF, "Implementing the Information Rights of Canadian Children" (2002). Law Publications. 54.

https://ir.lib.uwo.ca/lawpub/54 


\section{Westlaw Delivery Summary Report for FELDMANN,NICOLE}

Your Search:

Date/Time of Request:

Client Identifier:

Database:

Citation Text:

Lines:

Documents:

Images:
"IMPLEMENTING THE INFORMATION RIGHTS OF CANADIAN CHILDREN"

Friday, July 3, 2009 10:25 Central

UWO

CANPRIME-PLUS

20 CFLQ 429

1570

1

0

The material accompanying this summary is subject to copyright. Usage is governed by contract with Thomson Reuters, West and their affiliates. 
(Publication page references are not available for this document.)

20 CFLQ 429

\author{
Canadian Family Law Quarterly \\ Volume 20, No. 1 \\ 2002 \\ Implementing the Information Rights of Canadian Children \\ Margaret Ann Wilkinson[FN*] \\ Lynne (E.F.) McKechnie[FN**] \\ Copyright (C) Thomson Reuters Canada Limited or its Licensors. \\ All rights reserved.
}

\title{
1. -- Introduction[FN1]
}

On November 20, 1989, the General Assembly of the United Nations adopted the Convention on the Rights of the Child [hereinafter "the Convention"]. It was ratified by the requisite 20 nations and came into force within one year, in September 1990. Indeed, as Lawrence J. LeBlanc notes "The rapid and widespread acceptance of the Convention on the Rights of Child is impressive and remarkable. No other specialized United Nations human rights convention has been accepted so quickly and with such apparent enthusiasm."[FN2] Canada was part of this enthusiasm, signing the Convention on May 28, 1990 and ratifying it on December 13, 1991.

An area of the Convention that has been seldom discussed is its provision of information rights for children. One traditional institution providing information and entertainment to children is the public library. This article will examine the environment within which Canada's public librarians serve children and ask whether current practices in Canadian public libraries support Canada's obligations to children under the Convention or whether the practices of librarians in Canada's public libraries actually undermine Canada's efforts to adhere to the Convention. The article discusses the challenge of reconciling children's information rights in Canada under the Canadian Charter of Rights and Freedoms with those set forth in the Convention. The article then considers whether those practices of Canada's librarians that appear to undermine Canada's efforts to implement the provisions of the Convention are so deeply ingrained that statutory action is required to alter them.

\section{2. -- The Information Obligations in the Convention on the Rights of the Child}

There has been scholarly comment on the Convention of the Rights of the Child. [FN3] It has also been considered in the Supreme Court of Canada.[FN4] However, it has rarely been considered from the perspective of the rights to information for children that it contains.[FN5] Paradoxically, these rights are amongst the Convention's most far-reaching and comprehensive.

Article 13 of the Convention specifically states a child is entitled to certain rights in information:[FN6]

1. The child shall have the right to freedom of expression; this right shall include freedom to seek, receive and impart information and ideas of all kinds, regardless of frontiers, either orally, in writing or in print, in the form of art, or through any other media of the child's choice.

Article 17 is even more specific in describing the child's right to access various media. Several of its subsections 
appear to impose particular obligations on those who mediate between children and the sources of this information.

State Parties recognize the important function performed by the mass media and shall ensure that the child has access to information and material from a diversity of national and international sources, especially those aimed at the promotion of his or her social, spiritual and moral well-being and physical and mental health. To this end, the Parties shall:

(b) Encourage international co-operation in the production, exchange and dissemination of such information and material from a diversity of cultural, national and international sources;

(c) Encourage the production and dissemination of children's books;

$$
\text { ..... }
$$

Article 28 provides further, with respect to certain subject matter, in clause 3, that "State Parties shall promote and encourage international co-operation in matters relating to education, in particular with a view to . facilitating access to scientific and technical knowledge. ."[FN7] It should be noted that Canada was influential in instigating this article.[FN8] Finally, Article 31, clause 2, provides that, "State Parties shall respect and promote the right of the child to fully participate in cultural and artistic life and shall encourage the provision of appropriate and equal opportunities for cultural, artistic, recreational and leisure activity."[FN9]

Article 1 of the Convention establishes that the children to whom it applies are those under 18 years of age unless the age of majority in the member state is younger, in which case a "child" for purposes of the Convention is someone under the age of majority.

Canada is thus under a positive obligation to create an environment in the nation that ensures certain access to information for children, in the medium of the child's choice (Article 13), as well as through the mass media and children's literature (Article 17), particularly to scientific and technical information (Article 28, clause 3) and also to promote children's opportunities in culture, art, recreation, and leisure activities (Article 31).

Canada's adherence to this international convention is an indication by Canada's federal government of its intention to comply with that standard. [FN10] The sanctions available at the international level, of course, may be far from efficient in securing compliance by member states to their treaty obligations.[FN11] Much therefore continues to depend upon a signatory state's own domestic efforts to honour this international treaty. Canada, as a federated state, has particular challenges in this regard. As John Holmes comments:

It must, however, be noted that although Canada's interest in the field of human rights has always been strong, other factors intervened to prevent Canada from playing a more active role in the past and at times resulted in a very cautious position. In large measure, this hesitancy was the result of Canada's federal structure and the fact that much of the subject matter addressed in the human rights instruments fell within provincial or shared jurisdiction. [FN12]

For Canadian children, then, the real test of the effectiveness of this Convention on the Rights of the Child is the degree to which its provisions have been implemented meaningfully within both federal and provincial Canadian jurisdictions.[FN13] 


\section{3. -- Limitations on the Child's Right to Information Recognized in the Convention}

There is a tension in the Convention itself between the Articles that recognize the importance of the child's views[FN14] and those that focus upon issues of the child's welfare.[FN15]

The notion of separate rights for children is a comparatively recent social development. Sheena Scott describes the supremacy of the family as being the dominant notion at least up until just prior to the 1920s.[FN16] Since then, she says, children have been considered to have individual needs and personalities apart from their family identities.[FN17] However, Scott only dates the emerging notion of separate rights for children to the period between 1960 and 1980.[FN18] Michael Freeman also dates this emerging notion to the 1970s.[FN19]

Michael Freeman focuses upon Article 12 of the Convention as the epitome of its focus on the child's perspective:[FN20]

1. State parties shall assure to the child who is capable of forming his or her own views the right to express those views freely in all matters affecting the child, the views of the child being given due weight in accordance with the age and maturity of the child.[FN21]

He contrasts this with the tenor of Article 3, which begins in clause 1 with, "In all actions concerning children . the best interests of the child shall be a primary consideration." It is interesting that, under the Convention, the best interests of the child are to be "a" primary consideration, not necessarily "the" primary consideration.[FN22]

Article 18 provides in part:

(1) States Parties shall use their best efforts to ensure recognition of the principle that both parents have common responsibilities for the upbringing and development of the child. Parents or, as the case may be, legal guardians, have the primary responsibility for the upbringing and development of the child. The best interests of the child will be their basic concern.

(2) For the purpose of guaranteeing and promoting the rights set forth in the present Convention, States Parties shall render appropriate assistance t parents and legal guardians in the performance of their childrearing responsibilities and shall ensure the development of institutions, facilities and services for the care of children.

Article 5 sets out the role of parents under the Convention:[FN23]

States parties shall respect the responsibilities, rights and duties of parents, or, where applicable, the members of the extended family or community as provided for by local custom, legal guardians or other persons legally responsible for the child, to provide, in a manner consistent with the evolving capacities of the child, appropriate direction and guidance in the exercise by the child of the rights recognized by the present Convention.

Holmes points out that Article 5 was particularly difficult during the international negotiations leading to the treaty:

Throughout the drafting of the Convention, the question of the rights and duties of parents was a problemat- 
ic issue. While most states accepted the notion that governments should only intervene in family affairs in exceptional circumstances, there was concern that recognition of the rights of parents was an inappropriate inclusion in a convention aimed at elaborating rights and protections for the child. Nevertheless, an article [5] on this subject was included in the Convention.[FN24]

Article 5 originated in a proposal from the United States and Australia. Canada opposed its inclusion, arguing, "in protecting the family from the State, the family must not be given arbitrary control over the child. Any protection from the State given to the family must be equally balanced with the protection of the child within the family."[FN25] The clause remains and, together with Article 18, enshrines the primary role of parents in their children's lives -- but apparently the role is to be consistent with the child's evolving capacities to exercise her or his rights under the Convention.

In relation specifically to information issues, Article 17(e) of the Convention provides that States shall:

Encourage the development of appropriate guidelines for the protection of the child from information and material injurious to his or her well-being bearing in mind the provisions of articles 13 [the right to information] and 18 [concerning parental rights].

On this point, Geraldine Van Bueren argues:

This would appear to imply that because children's access to the mass media is often controlled by the parents the guidelines must not be so restrictive as to interfere either with parental discretion or to interfere with the child's rights of access to information.[FN26]

This logic does not seem persuasive since it appears to imply that any guidelines would need to defer to the parents' discretion, which appears to go well beyond the text of the Convention.[FN27]

Article 36 also gives the State responsibility to "protect the child against all other forms of exploitation prejudicial to any aspects of the child's welfare."[FN28] There is no context within this Article for defining "other forms of exploitation" but, if the phrase is given a wider meaning than the prohibitions on exploitation more specifically set out in the surrounding Articles,[FN29] it might well be interpreted widely enough to embrace the commercial exploitation of children through exposure to inappropriate information or entertainment.

\section{4. -- The Role Librarians in Canadian Public Libraries Play in Fulfilling Canada's Obligations Under the Charter}

Are Canadian governments discharging the information obligations created under the Convention? "Information" was not an area of legislative competence parcelled out to either the federal or provincial governments in 1867. "Education," on the other hand, was left exclusively to the provincial governments and certainly formal education systems can contribute to fulfilling these international obligations in providing information and recreation to children. However, formal education in Canada does not include all the children contemplated under the Convention: young children have not yet entered the education system and many students leave school before they would be considered adults under the Convention. Another potential partner for Canada in achieving the information goals of the Convention is the public library. The public library has long served Canadian residents of all ages and is specifically devoted to serving the recreation and information needs of the public.[FN30]

Public libraries have existed in Canada since well before Confederation. [FN31] Public libraries grew as com- 
munity institutions and are therefore considered to be "municipal institutions" under the exclusive legislative jurisdiction of the provinces.[FN32] Each of the provinces, having originally considered public libraries within their education portfolio, [FN33] then created independent legislation governing public libraries. [FN34] The role of the public library is well ingrained in Canadian life: for example, in Ontario by 1996, 99 per cent of the population was served by a public library.[FN35]

The public library legislation in Canada requires these libraries to provide services and information to the public.[FN36] However, none of the statutes mentions children specifically.[FN37] Nor, in fact, do the current statutes mention librarians.[FN38] It is, however, the case that professional librarians in public libraries throughout Canada are involved in providing information services to children.

Recognizing that none of the public library statutes in Canada creates any positive obligation on library employees to provide the services to children described in the Convention, is there any evidence to support the hypothesis that public libraries in Canada not only do not provide these services but in fact serve children in ways that are other than in accordance with Canada's obligations under the Convention?

\section{5. -- The Practice of Children's Librarianship in Canada}

If professional librarianship in Canada was a regulated profession in Canada, and unlicensed practitioners were prohibited from providing information services to the public,[FN39] then the standards set by the profession for providing services to children would be definitive evidence of Canada's efforts to comply with the Convention. However, librarians are not professionally regulated in any common law jurisdiction in Canada.[FN40]

On the other hand, there are a number of associations to which librarians and others involved in library services may belong. Chief among these are the American Library Association, the Canadian Library Association, and the provincial library associations. These associations all have both personal and institutional members -- and the personal memberships are open to any interested persons, whether or not they are educated as professional librarians. The oldest of these associations is the American Library Association [ALA], which was founded in 1876. From the beginning, it has had both an American and a Canadian membership base.[FN41] Its membership now exceeds 50,000.[FN42] The ALA is itself a National Association Member of the International Federation of Library Associations and Institutions [IFLA]. The Canadian Library Association [CLA] is also, as one of Canada's national associations, [FN43] a National Association Member of IFLA. The CLA was founded comparatively recently, in a mood of post-war nationalism, in 1946 and has a membership of about 4,500 members.[FN44] The provincial Ontario Library Association [OLA] is older and larger than its national counterpart, having been founded in 1900.[FN45] It has a current membership of about 4,000[FN46] and is the largest library association in Canada.

Each of these associations has promulgated standards for professional library practice.[FN47] In an unregulated profession, the dictates of "professional associations" may affect the actions of professionals, but do not bind them to any particular conduct. As John Swan so succinctly put it, "The LBR [Library Bill of Rights] is nobody's law; it is a declaration of guiding principles." [FN48] Without regulation, Canadian librarians are free to adopt policies from sources of their choosing, so long as they do not conflict with Canadian law. They are not required to be members of any association and are free to model their behaviour on any model as they see fit. However, educational programmes in library and information science across Canada discuss the policies of these associations in their courses and many librarians belong to at least one of these organizations, either personally or through their employing institution. Thus, it may be assumed that these associations influence library service in 
Canada and many Canadian librarians are aware of, and actually adopt into their own practice, the approaches to intellectual freedom advocated by these associations.[FN49] Is there evidence, then, that adopting any of the standards promulgated by these organizations would bring Canadian librarians into conflict with Canadian law or the dictates of the Convention?

\section{6. -- Do the Library Associations Give Appropriate Guidance to Librarians in Terms of Canada's Obliga- tions Under the Convention?}

The CLA has a four point Code of Ethics:

Members of the Canadian Library Association have the individual and collective responsibility to:

1. support and implement the principles and practices embodied in the current Canadian Library Association Statement on Intellectual Freedom;

2. make every effort to promote and maintain the highest possible range and standards of library service to all segments of Canadian society;

3. facilitate access to any or all sources of information which may be of assistance to library users;

4. protect the privacy and dignity of library users and staff.

The Statement on Intellectual Freedom, which this Code of Ethics incorporates by reference in point 1, has its origins several years before the Code of Ethics.[FN50] It advocates for open access to all persons in Canada.

The ALA has an eight point Code of Ethics.[FN51] The first four of these speak directly to its members' participation in providing information access:

1. We provide the highest level of service to all library users through . equitable service policies, equitable access.

2. We uphold the principles of intellectual freedom and resist all efforts to censor library resources.

3. We protect each user's right to privacy and confidentiality with respect to information sought or received and resources consulted, borrowed, acquired or transmitted.

4. We recognize and respect intellectual property rights.

The ALA, in addition to its Code of Ethics, has a Bill of Rights.[FN52] Subsection (5) of the Bill of Rights says precisely "A person's right to use a library should not be denied or abridged because of origin, age, background or views." [Emphasis added]. This may be contrasted with the CLA Statement on Intellectual Freedom, just discussed, which speaks in terms of the librarian's obligations to "all persons in Canada" and "all persons and groups."

The OLA, although it has no Code of Conduct, does have a Statement on the Intellectual Rights of the Individual, passed in 1990 and more recently revised. It also advocates for open access to information, without restriction, for all members of the public. Its preamble begins by reiterating the Association's "commitment to the fundamental rights of intellectual freedom, the freedom to read and freedom of the press, as embodied in the Canadian Charter of Rights and Freedoms."[FN53] There is no mention of the Charter's section 1 limitation on the 
rights and freedoms set out in it. The OLA has also adopted a Position on Children's Rights in the Public Library that states:

Children in Public Libraries have the right to:

1. Intellectual freedom.

2. Equal access to the full range of services and materials available to other users.

3. A full range of materials, services and programs specifically designed and developed to meet their needs.

4. Adequate funding for collections and services related to population, use and local community needs.

5. A library environment that complements their physical and developmental stages.

6. Trained and knowledgeable staff specializing in children's services.

7. Welcoming, respectful, supportive service from birth through the transition to adult user.

8. An advocate who will speak on their behalf to the library administration, library board, municipal council and community to make people aware of the goals of children's services.

9. Library policies written to include the needs of the child.

The OLA Statement on the Intellectual Rights of the Individual mentions the rights of the "citizen" and the "public" in framing its propositions. The OLA Position on Children's Rights does not define "children" but makes it clear that the library has a series of positive obligations to provide special resources and services to this group of users.

Relatively recently, the IFLA approved a Statement on Libraries and Intellectual Freedom,[FN54] which includes the following provisions:

IFLA believes that the right to know and freedom of expression are two aspects of the same principle. The right to know is a requirement for freedom of thought and conscience; freedom of thought and freedom of expression are necessary conditions for freedom of access to information.

IFLA therefore calls upon libraries and library staff to adhere to the principles of intellectual freedom, uninhibited access to information.

Libraries shall acquire, organize and disseminate freely and oppose any form of censorship.

Libraries shall make materials facilities and services equally accessible to all users. There shall be no discrimination due to age.

Librarians and other professional library staff shall fulfill their responsibilities both to their employer and to their users. In cases of conflict between those responsibilities, the duty towards the user shall take precedence. 
Thus, both the ALA and IFLA explicitly provide that children are to receive at least the same level of service and resources as other library patrons. The CLA implicitly makes the same provision. The provincial OLA provisions, on the other hand, impose specific positive obligations on libraries and librarians to serve the interests of children. The OLA's "full range of materials" could be broad enough to encompass the range of media contemplated in Article 13 of the Convention. While the Convention specifically emphasizes supporting the child in the areas of science and technology, social, spiritual and moral well-being, and physical and mental health, the OLA Position does not specifically give guidelines for collections or services other than to say they should be related to population, use, and local community needs and should complement the child's physical and developmental stages. Moreover, while the Convention specifically emphasizes books as a source for children, the OLA Statement does not discriminate between types of materials. While the Convention encourages diversity of cultural, national and international sources, the OLA Position makes no such requirements of libraries. On the other hand, the OLA, in its Statement on Intellectual Rights, makes direct reference to "the provision of access to electronic sources of information, including access to the internet."

These Codes and Statements would all lead libraries and librarians in Canada to provide information to children in Canada, which would be consistent with the information provision aspects of the Convention. Under the Convention, however, Canada has an obligation to balance the right of access with both the proper role of parents as set out in the Convention and the obligation to provide "guidelines for the protection of the child from information and material injurious to his or her well-being." Do these Codes contemplate this balancing?

The IFLA Statement, CLA policy documents, and OLA policies are not qualified in any way.[FN55] The ALA, on the other hand, despite making the explicit declaration in its Library Bill of Rights that age should not abridge a person's right to use the library, has created a subsidiary document that appears expressly to advise librarians to defer to parents in determining the access to materials to be given to children. The document called "Free Access to Libraries for Minors: An Interpretation of the Library Bill of Rights," adopted by ALA Council,[FN56] contains the following passage:

Librarians and governing bodies should not resort to age restrictions on access to library resources in an effort to avoid actual or anticipated objections from parents or anyone else. The mission, goals, and objectives of librarians do not authorize librarians or governing bodies to assume, abrogate, or overrule the rights and responsibilities of parents or legal guardians. Librarians and governing bodies should maintain that parents -- and only parents -- have the right and the responsibility to restrict the access of their children -- and only their children -- to library resources. Parents or legal guardians who do not want their children to have access to certain library services, materials or facilities, should so advise their children. Librarians and governing bodies cannot assume the role of parents or the functions of parental authority in the private relationship between parent and child. Librarians and governing bodies have a public and professional obligation to provide equal access to all library resources for all library users. [Emphasis added.]

The ALA Policy Manual draws on this longer statement, as indicated in the italicized section above, and declares, at paragraph 53.1.4 that:

Denying minors access to certain library materials and services available to adults is a violation of the Library Bill of Rights. Librarians and governing bodies should maintain that parents -- and only parents -- have the right and responsibility to restrict the access of their children -- to library resources.[FN57]

The excerpt may be infelicitous, at best, and perhaps even misleading.[FN58] In the longer Statement, it is clear 
that the appropriate avenue for parental input to the process of restricting access is through their own children -the librarians (and library management) would therefore always respond to the child's expressed requests. In the shorter passage in the Manual, it might be thought that the librarians and library administration should respond to the parents' expressed views directly.[FN59] Even the fuller Statement, however, declaring that "[1]ibrarians and governing bodies cannot assume the role of parents or the functions of parental authority in the private relationship between parent and child" begs questions such as "what are the limits of that private relationship between parent and child? When, if ever, do the public and professional obligations of the librarian and governing body take precedence over parental authority?"

In addition to the policy statement on "Free Access to Libraries for Minors" just discussed, the ALA also adopted, in 1999, a policy statement entitled "Libraries: An American Value."[FN60] In this document, the ALA first declares "we defend the constitutional rights of all individuals, including children and teenagers, to use the library's resources and services," and then declares "we affirm the responsibility and the right of all parents and guardians to guide their own children's use of the library and its resources and services."

In the documents created prior to 1999, the ALA appears to have attempted to avoid controversy: the librarian and the library administration will have discharged their obligations if the needs of the child as expressed to the librarian have been met. Whether or not the parent has previously censored the child's expression of his or her own needs is not for the librarian or the library to investigate. Whether the parent is exercising "appropriate direction and guidance," as required under Article 5 of the Convention, will not be investigated by the librarian or library adopting the ALA approach. This approach, in deferring so much to the parent, seems to go beyond the balance required under the Convention discussed above.

The 1999 ALA policy statement creates an internal tension between two principles (the rights of the child and the rights of the parent), which it then does nothing to resolve. Furthermore, all the ALA policy documents mentioned are simultaneously in force at the moment. In none of them is any mention made of any requirement that the library itself provide protection for children from injurious information (see discussion of Article 17 of the Convention, above).

The more the child's capacity becomes sufficient to appropriately handle the information guaranteed under the Convention (Article 13, specifically, and Articles 17, 28 and 31, implicitly), the more the parents' rights guaranteed under the Convention are to direct and guide the child in exercising the rights provided (paraphrasing from Article 5), not to block the child's exercise of those rights. Nothing in the ALA position (or positions) reflects this approach.

This Convention does not have a petitioning system and so individual children cannot use the Convention directly.[FN61] As both the majority and minority judges in the Baker v. Canada (Minister of Citizenship \& Immigration) case in the Supreme Court of Canada agreed, "the Convention has not been implemented by Parliament. Its provisions therefore have no direct application within Canadian law."[FN62] Since the Convention is not received law in Canada and has not been legislatively implemented, its provisions cannot have a direct legal application to Canadian libraries and librarians.[FN63] However, the Supreme Court of Canada has taken the approach, in the majority judgment in Baker, that, ". the values reflected in international human rights law may help inform the contextual approach to statutory interpretation and judicial review." [FN64] The applicability of the Convention on the Rights of the Child was specifically in issue before the Supreme Court of Canada in Baker (and was, indeed, the issue over which the judges in the majority and minority disagreed).[FN65] The majority of the Court sided with Mme Justice L'Heureux-Dubé in holding that, "The . principles of the Convention . place 
special importance on protections for children and childhood, and on particular consideration of their interests, needs, and rights. They help show the values that are central in determining whether this decision was a reasonable exercise of the H \& C [humanitarian and compassionate] power [of the Canadian federal department of Immigration]."[FN66] It would therefore appear that librarians and libraries in Canada could find their policies and actions with respect to services to children reviewed by courts in light of the provisions of the Convention even though the provisions of the Convention have not been directly adopted into Canadian legislation. It is not clear how courts might interpret the activities of librarians that are inconsistent with the provisions of the Convention but inspired by positions taken by the major library associations. This is the case because the Convention is not to be applied directly but is to be used indirectly as an interpretive factor informing the contextual approach to statutory interpretation and judicial review.

What guidance is there in Canadian law for librarians attempting to meet the needs of children?

\section{7. -- Information Rights in Canadian Law}

Since 1982, a formal source for rights in Canada has been the Canadian Charter of Rights and Freedoms.[FN67] Although an important aspect of Canadian constitutional law since its inception, the Charter's application in Canada is limited to situations involving government action.[FN68] However, since public libraries are statutorily created or continued institutions, the actions of their Boards and employees are open to scrutiny under the Charter. In any event, there has also been opinion in the Supreme Court of Canada that judges throughout Canada should interpret all law in such a way that "Charter values" are expressed throughout Canadian law.[FN69]

Chief among the rights involving information in the Charter is the section 2(b) right to freedom of expression.[FN70] This right is expressed succinctly in a subsection that also includes protection of freedom of thought, belief, and opinion. This grouping may be contrasted with that in the Convention where freedom of thought and conscience are grouped with freedom of religion[FN71] as the subjects of Article 14, while the right to freedom of expression is dealt with in a different, distinct, provision: Article 13, quoted above. In the Canadian Charter, the right to freedom of expression is not as fully amplified as it is in the Convention,[FN72] although it is stated to include "freedom of the press and other media of communication." Whereas the Convention specifically states that freedom of expression shall include the freedom to seek and receive information, the right of access to information has been confirmed to be part of the rights protected by the Charter in Canada only through judicial interpretation of the notion of freedom of expression. [FN73]

It may be important to note in this context that, when writing the minority judgment in the Baker case, although he would not apply the Convention indirectly in that case, Mr. Justice Iacobucci did point out that the dissent was dependent upon the fact that the case did not raise issues involving the Canadian Charter of Rights and Freedoms. As he stated (at paragraph 81):

. I am mindful that the result may well have been different [in the opinion of the judges in the minority] had my colleague [Mms Justice L'Heureux-Dubé, writing for the majority] concluded that the appellant's claim fell within the ambit of rights protected by the Canadian Charter of Rights and Freedoms. Had this been the case, the Court would have had an opportunity to consider the application of the interpretive presumption, established by the Court's decision in Slaight Communications Inc. v. Davidson, [1989] 1 S.C.R. 1038 (S.C.C.), and confirmed in subsequent jurisprudence, that administrative discretion involving Charter rights be exercised in accordance with similar international human rights norms. 
The Charter protection in section 2(b) in Canada operates to ensure that access to information cannot be impeded through government action (except as permitted under section 1 of the Charter), but it does not place anyone under a positive duty to provide access. The Convention, meanwhile, has imposed positive duties on Canadian governments to "ensure that the child has access to information and material from a diversity of national and international sources" (Article 17), to "promote and encourage international co-operation . with a view to . facilitating access to scientific and technical knowledge ." (Article 28), and to "promote [. participation] in cultural and artistic life" (Article 31).

\section{8. -- Limitations on the Child's Right to Information in the Charter}

The Charter generally prohibits discrimination between adults and children:

s. 15(1) Every individual is equal before and under the law and has the right to the equal protection and equal benefit of the law without discrimination and, in particular, without discrimination based on . age.

However, such discrimination will be permitted in certain circumstances:

s. 15(2) Subsection (1) does not preclude any law, program or activity that has as its object the amelioration of conditions of disadvantaged individuals or groups including those that are disadvantaged because of . age.

And, as well, of course, all the rights enumerated in the Charter, including those in sections 2(b) and 15, are tempered by section 1 of the Charter, which provides for legitimate limitations on the rights enumerated:

The Canadian Charter of Rights and Freedoms guarantees the rights and freedoms set out in it subject only to such reasonable limits prescribed by law as can be demonstrably justified in a free and democratic society.

It is entirely conceivable, then, that the right of the child to access information can still be legitimately limited by the federal or provincial governments in Canada if the limitation can be "demonstrably justified in a free and democratic society." Although such limitations may be domestically open to Canadian governments, such limitations may not be consistent with Canada's obligations as signatory to the Convention. Under the Convention, as discussed, the child's rights to information are more fulsomely expressed than is the right under the Charter. Under the Convention, the only limitations on the child's rights that could be justifiable are those protecting the child from exploitation prejudicial to his or her welfare under Articles 17(e) or 36. [FN74] On the other hand, it is not certain how the rights in the international Convention that recognize the child's subjective views and those based upon a more objective view of the child's welfare are to be balanced (as discussed above). The Charter, in section 1, does provide a formula for balancing such interests as those set out under Article 17(e) of the Convention.[FN75]

Unless the right of the child to access information, guaranteed as part of the Charter's section 2(b) commitment to freedom of expression, is expressly limited by government action in a way that can be reasonably and demonstrably justified in a free and democratic society, it would appear that censoring children's access to information in public libraries, beyond what is done with respect to adults' access, would violate the child's guaranteed Charter rights in Canada. The Charter does permit the government to place reasonable limits on the child's right to information and such limitations could be consistent with Canada's obligations under the Convention if they achieve the balance alluded to under the Convention Articles discussed above. This begs the question, however, 
whether public library policies limiting children's rights of access can be reasonably and demonstrably justified in a free and democratic society. In attempting to interpret the Charter rights of Canadian children in light of the information rights set out in the Convention, the Supreme Court will certainly be challenged. It will have to consider the complexity of the relationship between, on the one hand, the balance required under the Convention between the information rights of the child and the rights of the parents in bringing up their child and, on the other hand, the balance required between the rights enumerated in the Charter and the reasonable limits on those rights that are permitted in our free and democratic society by the Charter.

\section{9. -- Do the Library Associations' Guidelines Provide Any Justification for Censoring Children's Access to Information?}

IFLA specifically opposes any form of censorship.[FN76] Presumably this would include the censoring of children's access to information by their parents or by the state, even for the child's welfare. The CLA Statement on Intellectual Freedom implicitly involves libraries in resisting censorship. [FN77] The OLA deals circuitously with the question of censorship, but ends up resisting it:

1) the provision of library service to the public is based upon the right of the citizen, under the protection of the law, to judge individually on questions of politics, religion and morality.

2) it is therefore part of the library's service to its public to resist any attempt by any individual or group within the community it serves to abrogate or curtail access to information, the freedom to read, view and listen by demanding the removal of, or restrictions to library sources in any format. [FN78]

On the other hand, while generally opposing censorship in its Code of Ethics (paragraph II), the ALA specifically states, "We recognize and respect intellectual property rights." (Paragraph IV.)[FN79] Other than in the area of intellectual property rights presumably (although not specifically), the ALA Library Bill of Rights specifically charges libraries to "challenge censorship" and "cooperate with all persons and groups concerned with resisting abridgement of free expression and free access to ideas."

None of the library association positions specifically recognizes legal censorship of information (with the exception of the ALA's regard for intellectual property already mentioned). Their positions range from apparent tacit acceptance of legal censorship by the OLA, to implicit opposition by the CLA, to overt opposition at IFLA and an active obligation to challenge such censorship in the ALA.

All of the associations require positions of their members, which appear to be inconsistent with the position taken by the Convention that guidelines are to be provided to protect children from information injurious to their welfare. None of the associations provides librarians with any justification for limiting a child's right of access to information. As has been discussed above, however, the Convention does recognize that a state may place certain limitations on a child's rights to information. The Convention particularly permits the limiting of the child's rights where these rights are limited in favour of the guidance and direction of parents or guardians, acting in the child's best interests, while the child has a lesser capacity to act on his or her own. Is there, however, a justification for limiting the child's access available to librarians under Canadian law?

\section{0. -- "Children" in Canadian Law}

The law in Canada is complex concerning the capacity of children in various situations. In the decision of the Supreme Court of Canada in B. (R.) v. Children's Aid Society of Metropolitan Toronto, the question of the role 
of parents in society was at the heart of the dispute.[FN80] Interestingly, the Court made no reference to the Convention on the Rights of the Child in the decision. The case involved the right of parents to deny their infant child a blood transfusion on religious grounds but as Mr. Justice La Forest noted in his judgment, "this appeal raises the more general question of the right of parents to rear their children without undue interference by the state." [FN81] While they concurred in the result in this particular,[FN82] the nine Supreme Court Justices were sharply divided about whether section 7 of the Canadian Charter of Rights and Freedoms included, as a basic right, the parent's right or liberty to parent a child.[FN83] As Mr. Justice La Forest phrased it, speaking for himself, Mme. Justice L'Heureux-Dubé, Mr. Justice Gonthier, and Mme. Justice McLachlin (as she was then), "parental decision making must receive the protection of the Charter in order for state interference to be properly monitored by the courts, and be permitted only when it conforms to the values underlying the Charter."[FN84] He continued:

Once it is decided that the parents have a liberty interest, further balancing of parents' and children's rights should be done in the course of determining whether state interference conforms to the principles of fundamental justice, rather than when defining the scope of the liberty interest. Even assuming that the rights of children can qualify the liberty interest of their parents, that interest exists nonetheless.[FN85]

Chief Justice Lamer (as he was then), speaking only for himself, directly dissented on this point and wrote that parental liberty falls outside the ambit of section 7.[FN86] He pointed out that the majority of the Court in adopting this line of reasoning had picked up an approach that had heretofore only been adopted by Mme. Justice Wilson, in the dissent in the Supreme Court of Canada decision of $R$. v. Jones.[FN87] Mr. Justices Iacobucci and Major, speaking for themselves and Mr. Justice Cory, meanwhile, were concerned that the approach taken by Mr. Justice La Forest might be retrogressive,[FN88] and yet were unwilling to use this case as the vehicle for limiting section 7 as the Chief Justice had done.[FN89] They were thus left with at least a more qualified view of the parental rights encompassed by section 7 than Mr. Justice La Forest, and definitely believed the "parental decision to withhold medical care to be outside the scope of 'liberty"' in section 7.[FN90]

The right of librarians to limit the child's rights under Canadian law only becomes an issue, of course, if librarians are, in fact, placing limitations upon children's access.

\section{1. -- Do Libraries Actually Limit Children's Access to Information in Canadian Libraries?}

There is considerable evidence that, despite the overwhelming stands taken by their library associations, librarians and libraries do systematically limit children's access to information resources and services. As Marilyn Gell Mason writes:

In spite of the official ALA position outlined in the Library Bill of Rights . that there should be free and open access to all library materials for everyone, regardless of age, including material on the Internet, libraries across the country are experimenting with some mechanism for limiting children's access, at least to the seamier sites. Some are using the technological solution of filtering software; others have sought legal sanction by requiring parental approval for children to use the Internet; still others rely on behavioural responses such as making the computer screen public, making the computer screen private, or asking users to desist when viewing offensive images.[FN91]

In one of the major tools used by librarians in developing children's services in libraries, Ann Symons and Charles Harmon interpret the ALA Library Bill of Rights by making the following excerpt from that document: 
Library policies and procedures which effectively deny minors equal access to all [emphasis added by Symons and Harmon] library resources available to other users violate the Library Bill of Rights. [The first sentence of the Interpretation, the passage which completes the quote is from midway into the fifth paragraph.]. Librarians and governing authorities should maintain that parents -- and only parents -- have the right and responsibility to restrict the access of their children -- and only their children -- to library resources. Parents or legal guardians who do not want their children to have access to certain library services, materials or facilities, should so advise their children.[FN92]

They then go on to assert unequivocally that:

- Parents can and should advise their own children on what they consider appropriate for them to read, hear, and view;

- Parents can and should enforce their wishes by dealing directly with their children;

- Parents do not have the right to impose their views on other parents or other people's children;

- Librarians do not and should not have the authority to monitor or restrict any patron's reading; and

- Librarians who set up or adopt 'restricted' library cards or practices violate the Library Bill of Rights.[FN93]

The authors do not expressly give direction to librarians in the situation in which a parent attempts to give instructions about their own child's information access to the librarian. Yet Mary K. Chelton believes that this is precisely the difficult question: "In youth services librarianship, the overriding access issue is the degree to which the librarian function in loco parentis and the degree to which youth-serving librarians should function that way. Put simply, the issue is whether the child or the parent is the primary client."[FN94]

Kay Vandergrift cites various empirical studies demonstrating that, whatever the meaning of the ALA policy documents, many libraries operate in ways that limit the child's participation in accessing information through the library:

Many public libraries require parental permission to circulate certain books, a fairly typical way to handle controversial items or those that are potentially problematic. Another common approach to controlling access by children is to allow parents to decide whether to permit access for their children to the library's adult materials. . Some libraries even require an 'in-person' visit by adults to complete the registration. . King's research demonstrates the range of exceptions to circulation policies [which differentiate children's access to resources from that of adult patrons]. . It is not uncommon, however, for libraries to restrict access to computers by one of the groups of users most comfortable with them, that is, young people.[FN95]

A Canadian example of such an institutionalized policy is the basis for one of the few reported legal decisions in Canada involving libraries. Berger J., made a finding of fact in Edmonton (City) Library Board v. Morrill that "Clinton was 14 years old at that time and the plaintiff [the Edmonton Public Library] would not issue a library card to him unless an adult accepted responsibility for the use of the card."[FN96]

In commenting on such policies, Vandergrift says, rather tellingly, "Conscientious professionals may still be concerned about the intellectual opportunities for those young people whose parents deny them access to materials, but at least the library itself is not denying access."[FN97] However, this conclusion, unfortunately for the 
comfort of librarians, cannot be logically substantiated. If the child wants access, and the library's policy requires parental involvement, then it is the library that denies the child access on the ground of the parent's lack of involvement when that lack of involvement is demonstrated. Frances McDonald illustrates the common paradox involved in the librarian's perspective on censorship:

Common beliefs within the profession suggest that outsiders impose restrictions on access to information. While this may be partially true, practices that inhibit access are more often imposed by professionals working in school library media centers and public libraries than are imposed by persons outside the profession. Admittedly, pressure felt from outside groups contribute to in-house restrictions. But the amount of concern raised by and devoted to the citizen censor shifts the focus from the area of primary concern -- i.e. professional attitudes and practices resulting in restricting access to information.[FN98]

One example of an external group working to create change in libraries' policies is the Family Friendly Libraries movement in the United States. This group seeks to have libraries implement policies that specifically, among other things, "would have libraries bar unaccompanied children from accessing the adult collection and scrutinize materials for children's and YA [young adult] collections for anything that might be offensive."[FN99] The group specifically encourages librarians to reject the standards of professionalism in certain areas being promulgated by the America Library Association and adopt an alternative set of values.[FN100] As discussed above, librarians are legally free to choose to adopt the standards of their choice, not necessarily those promulgated by any one organization, but should not adopt standards that lie outside the boundaries of their legal obligations.

Currently there are numerous examples of public libraries in Canada and in the United States installing filtering software on the networked computers that are provided for children to access in the library.[FN101]

Even a library that specifically sought to clarify the boundaries placed by law upon its treatment of child patrons experienced challenge in implementing the advice it received, describes Janet Hildebrand.[FN102] In that case, the Contra Costa County Library was concerned about the privacy of children's circulation records when their parents enquired. It retained legal counsel and received unequivocal advice, which the article quoted verbatim, that "Absent a person's written authorization, or an order of the superior Court, no one, including a minor's parents, has a right to know what a person checks out of the public library."[FN103] Hildebrand described three areas of developing concern among library staff as a direct result of the unequivocal legal advice the library received: (1) parents co-signing to be financially responsible on the child's card (recall the Canadian Morill case mentioned above); (2) placing a lower limit on the age for cardholders; and (3) the parent's role as censor. On the first issue, the author concluded, based on a practical analysis, children should sign for their own cards, without parental involvement. [FN104] One the second issue, Hildebrand focused less on justifying the existence of such a policy but still seems to favour a lower age limit being placed on borrowers.[FN105] One the third, Hildebrand states of the Library that "If there are materials they [the parents] do not want their child to check out, we tell them to advise their child of this."[FN106] Hildebrand notes, "the concept that the child has rights apart from parents or family is a new idea to many parents and may be hard for them to understand or accept. Furthermore, the legal precedents are not clear."[FN107]

Librarians do not appear always to be aware whether they are applying professional judgment alone or whether they are acting under a legal duty. The position of public librarians in Canada with respect to managing video collections illustrates this situation.[FN108]

\section{2. -- Managing Children's Video Collections in Canada}


As the Ontario Law Reform Commission concluded in 1992, "[b]ased on existing jurisprudence, the constitutional competence to regulate the exhibition, sale, and exchange of films belongs to the provincial governments and not the federal government."[FN109] The laws of the provinces, however, are not uniform in their treatment of public libraries with respect to film collection and distribution. In most provinces, the laws regulating films, including videos, do not generally exempt public libraries from their provisions: Alberta, Manitoba, New Brunswick, Nova Scotia, Ontario and Saskatchewan.[FN110] British Columbia's Motion Picture Act, on the other hand, exempts "a public library" from the definition in the statute of a "motion picture distributor" (section 1), which appears to have the effect of exempting public libraries entirely from the operation of the Act.[FN111] A more limited exemption from the censorship regime exists in Quebec where the Cinema Act provides in section 77: "The following films are exempt from classification: . (2) films made for educational or pedagogical purposes, providing that they are used . in a public library."[FN112]

It is interesting to note that in Nova Scotia, the Board established pursuant to the legislation just discussed, banned the critically acclaimed film "Bastard Out of Carolina," directed by Angelica Huston.[FN113] A spokesperson for the Board was quoted as "acknowledging [the film's] redeeming social value" and saying "[t]he intent of Huston's film was obviously not pornographic."[FN114] However, the Board "deemed its depictions of child sexual abuse too graphic" and another spokesperson was quoted as saying "[i]t just goes beyond acceptable community standards."[FN115] While this decision to ban the film directly affected Maritime public libraries,[FN116] the same ban, if ordered in British Columbia, would apparently not have bound public libraries. In Quebec, the public libraries would not have been bound by such a classification if the film was "made for educational or pedagogical purposes." In Saskatchewan, the public library could not have shown the film (see subsection 2(d), definition of "exhibition"), but may have been able to circulate it because "distribution" under subsection 2(c) applies only to retail or wholesale distribution. This would also appear to be the case in New Brunswick; see sections 7 to 10 .

Where not bound by Canadian provincial laws (e.g., in British Columbia and, in some cases, in Quebec), Canadian librarians can fall back on the guidance of the American Library Association.

Deborah L. Vroman discusses the problem facing librarians in the United States now that the Motion Picture Association of America has voluntarily adopted a system of ratings.[FN117] These ratings do not have the force of law -- and therefore librarians can consider them in light of the American Library Association "Statement on Labelling: An Interpretation of the Library Bill of Rights," which condemns all labelling other than that for directional purposes. [FN118] Vroman points out, however, that that policy seems to be in conflict on this issue with the American Library Association's own policy as set out in "Access for Children and Young People to Videotapes and Other Nonprint Formats."[FN119] The latter policy states:

Published reviews of films and videotapes and/or reference works which provide information about the content, subject matter, and recommended audiences can be made available in conjunction with non-print collections to assist parents in guiding their children without implicating the library in censorship. This material may include information provided by video producers and distributors, promotional material on videotape packaging, and Motion Picture Association of America (MPAA) ratings if they are included on the tape or in the packaging by the original publisher and/or if they appear in review sources or reference works included in the library's collection. Marking out or removing ratings information from videotape packages constitutes expurgation or censorship.

MPAA and other rating services are private advisory codes and have no legal standing. For the library to 
add such ratings to the materials if they are not already there, to post a list of such ratings with a collection, or to attempt to enforce such ratings through circulation policies or other procedures constitutes labelling, "an attempt to prejudice attitudes" about the material, and is unacceptable. The application of locally generated ratings schemes intended to provide content warnings to library users is also inconsistent with the Library Bill of Rights. [Footnote omitted, emphasis in the original.] [FN120]

This seems a curious position from a number of perspectives. A paternalistic attitude seems evident in that the evaluative material about the collection is assumed to be made available to meet parents' needs. Why would not such material also be useful to the child? Why, if "[m]arking out or removing ratings information . constitutes censorship," is the injunction to make such information available (in the preceding sentence of the policy) only permissive -- "can be made available" -- instead of hortatory -- "should be made available"? The injunction not to restrict circulation of this material based on age in the preceding paragraph is hortatory.[FN121]

The caveat in the ALA policy that MPAA ratings can only be made available if they are on the tape or made available by the original publisher seems particularly odd: why does when the information is received or the way it is packaged determine whether or not it should be censored? Why is the provision of information to patrons about others' views on the subject matter of material held in the library considered an unacceptable "attempt to prejudice attitudes"? Surely it is just information -- unless the ratings system rather than the librarian's own judgment is being used to determine collections policy. And, assuming for the moment that provision of such information is inappropriate, then why, since the MPAA has no higher standing in the eyes of the law than any other system, is its system appropriate in the eyes of this policy? Finally, the policy says MPAA ratings may be made available from "sources or reference works included in the library's collection" -- which seems to place a bizarre emphasis on the library's own reference collection policy -- why not works held by others? To the extent that this policy is inconsistent with the American Library Association's general policy on labelling, then it would seem that this children's and young people's policy is displaying traditional paternalistic approaches to children - which may, in turn, be fundamentally inconsistent with developing legal trends in children's rights.[FN122]

\section{3. -- Conclusion}

It would appear that the positive obligations to provide children with access to information that Canada assumed when it signed the United Nations Convention on the Rights of the Child have not yet been implemented visibly in domestic legislation affecting public libraries. The Canadian Charter of Rights and Freedoms guarantees the same right to information to both children and adults, although the Charter would permit appropriate derogation from this right, as discussed above. Indeed, the Convention appears to recognize as legitimate more limitation on the child's rights to information than either the Canadian Charter or the intellectual freedom manifestos of the library associations, particularly in favour of the parents' role in determining appropriate access to information for children. While the Convention recognizes the right of parents to exercise a limiting control or guidance over children in exercising their rights to information, it does not generally recognize any such right in third parties (such as the employees of the public library). The only exceptions to this statement are in cases where the restraint is exercised in order to protect the child against exploitation prejudicial to the child's welfare or under government guidelines to protect the child from injurious material or information.

The Canadian Charter of Rights and Freedoms is silent on the question of parental rights. However, the Supreme Court of Canada has dwelt at length on the role of the parent, apparently recognizing at least some "parental rights" as guaranteed under section 7 of the Charter (without mentioning the existence of the international Convention on the Rights of the Child). The Court, in the $B$. (R.) case, discussed above, chose to speak very 
little, if at all, about the individual rights of the child, as opposed to the child's best interests.

The Convention contemplates, at least in some Articles involving information rights, a balancing of the child's rights with the appropriate role of the parents in the child's upbringing. The professional codes guiding librarians have predominantly come to champion the child's rights, rather than the parents' rights to speak for the child. On the other hand, recent behaviour in public libraries has increasingly indicated a willingness to limit the rights of children to access information, either outright or in favour of the parents' guidance. This behaviour could be subject to Charter scrutiny in Canada. Since the Supreme Court of Canada has indicated that it would be prepared to interpret the Charter in this area with an eye to the provisions of the Convention, it would seem important for public libraries and librarians to try to develop balanced policies reflecting the values of both the Charter and the Convention. The current policy statements of the major library associations do not demonstrate the requisite balance, as we have discussed above, and therefore cannot serve as appropriate models. The balancing, as also discussed above, is very challenging. Legislation is probably needed to guide the activities of librarians in public libraries in this undertaking. It would certainly appear that public librarians in Canada could be guided by such legislation into becoming much stronger instruments for Canada in achieving its obligations under the Convention than they now appear to be. This would be especially true if Canadian public librarians were given the statutory mandate (and requisite financial support) to carry out the positive information obligations placed upon Canada through signing the Convention.

FN*. Associate Professor, Faculty of Law and Faculty of Information and Media Studies, University of Western Ontario.

FN**. Associate Professor, Faculty of Information and Media Studies, University of Western Ontario.

FN1. The authors would like to thank former law student Tammy Smith and current law students Kelly Zalec and Jonathan Mesiano-Crookston for their research assistance on this paper. The authors are also grateful to library and information science student Catherine M. Simons for her help on an earlier related paper: Lynne McKechnie and Margaret Ann Wilkinson, "Do Canadian Children Have a Right to be Intellectually Free?" in Bernd Frohmann, ed. Communication and Information in Context: Society, Technology, and the Professions: Proceedings of the 25th Annual Conference of the Canadian Association for Information Science (St. John's, Newfoundland, 1997) at 56-67. The authors are also grateful to Professor Ben Hovius of the Faculty of Law, University of Western Ontario, for helpful comments on an earlier version of this paper.

FN2. Lawrence J. LeBlanc, The Convention on the Rights of the Child: United Nations Lawmaking on Human Rights in volume 3 of Human Rights in International Perspective, David P. Forsythe, ed. (Lincoln, Nebraska.: University of Nebraska Press, 1995) at xi.

FN3. For example: LeBlanc, ibid.; Geraldine Van Bueren, The International Law on the Rights of the Child (The Hague: Kluwer Law International, 1998); John Holmes, "The Convention on the Rights of the Child: A Canadian Perspective," in Preserving the Global Environment: Proceedings of the 18th Annual Conference of the Canadian Council on International Law (Ottawa: 1989) at 21.

FN4. Baker v. Canada (Minister of Citizenship \& Immigration), [1999] 2 S.C.R. 817, 1999 CarswellNat 1124, 1999 CarswellNat 1125.

FN5. An exception is Chapter 5 in Van Bueren, above, note 3. 
(Publication page references are not available for this document.)

FN6. Clause 2 of Article 13 creates certain caveats on the rights set out in clause 1 that are not relevant to the present discussion:

2. The exercise of this right may be subject to certain restrictions, but these shall only be such as are provided by law and are necessary:

(a) For respect of the rights or reputations of others; or

(b) For the protection of national security or of public order (ordre public), or of public health or morals.

FN7. LeBlanc, above, note 2, has divided his analysis of the Convention into a schemata of rights: survival rights, membership rights, protection rights, and empowerment rights. It is interesting to note that the foregoing Articles, 13, 17 and 28, are included in his chapter 6 "Empowerment Rights."

FN8. Holmes, above, note 3 at 23, reports that an early federal/provincial working group in Canada created an effective Canadian presence during the negotiation of the Convention and credits this group with the genesis of several sections, including Article 28.

FN9. This right does not appear to have been included by LeBlanc, above, note 2, under any of his four headings.

FN10. In the Baker case, above, note 4, Mr. Justice Iacobucci, speaking in the dissent for himself and Mr. Justice Cory, still agreed with the majority of the Supreme Court of Canada that the executive branch of the Canadian government had undertaken international obligations by signing this Convention. As discussed further below, the majority of the Court, for which Mme Justice L'Heureux-Dubé wrote, has taken the significance of that intention further than the two dissenting judges would have. As Mr. Justice Iacobucci wrote in dissent:

I do not agree with the approach adopted by my colleague, wherein reference is made to the underlying values of an unimplemented international treaty in the course of the contextual approach to statutory interpretation and administrative law, because such as approach is not in accordance with the Court's jurisprudence concerning the status of international law within the domestic legal system.

FN11. As Holmes points out, above, note 3 at 27, concerning the Convention on the Rights of the Child, "the implementation system is based on the reporting obligations of states and is thus subject to the same type of difficulties being experienced by other treaty-based bodies."

FN12. Holmes, above, note 3 at 22.

FN13. Terri Sussel's book Canada's Legal Revolution: Public Education, the Charter, and Human Rights (Toronto: Emond Montgomery, 1995) examines just this question for the issues of educating children with special needs, the AIDS crisis in education, women's equality rights in education, and religious values. Sussel does not discuss information rights.

FN14. These articles are identified by LeBlanc, above, note 2, as empowering: those involving freedom of expression, freedom of information, freedom of thought and religion, freedom of association and assembly, and the right to education. 
(Publication page references are not available for this document.)

FN15. Such as Article 36 just quoted.

FN16. Sheena Scott, "From Major to Minor: An Historical Overview of Children's Rights and Benefits" (1993) 9 J. L. \& Soc. Pol'y 222 at 235.

FN17. Ibid. at 235-238.

FN18. Above, note 16 at 238-239.

FN19. Michael Freeman, "Whither Children: Protection, Participation, Autonomy?" (1994) 22 Man. L. J. 307 at 312-315.

FN20. Ibid. at 320.

FN21. Section (2) of Article 12 deals with the child's particular right to be heard in judicial or administrative proceedings.

FN22. Mme Justice L'Heureux-Dubé, in writing the majority judgment in the Baker case, above, note 4 at para. 69 , reflects the duality of interest in the international conventions in this area, including this Convention:

Another indicator of the importance of considering the interests of children when making a compassionate and humanitarian decision is the ratification by Canada of the Convention on the Rights of the Child, and the recognition of the importance of children's rights and the best interests of children in other international instruments ratified by Canada. [Emphasis added.]

FN23. LeBlanc, above, note 2 at 112, sees Article 5 as "the basic framework" of the family rights articles, if not of the whole Convention. In apparent contrast, Freeman, above, note 19 at 319, sees "Article 12, the article providing for a child's participation in decisions affecting him or her . [as] the linchpin of the Convention."

FN24. Holmes, above, note 3 at 25.

FN25. LeBlanc, above, note 2 at 113, quoting United Nations Commission on Human Rights, "Question of a Convention on the Rights of the Child: Report of the Working Group on a Draft Convention on the Rights of the Child" (E/CN.4/1988/28, April 6).

FN26. Van Bueren, above, note 3 at 134.

FN27. Van Bueren, above, note 3 at 135, further argues that the concept of injurious material and information can extend to injury to the child's morals, and that this concept is so subjective that such injury should only be determined by reference to the child's own subjective view of her or his rights. In support of the former proposition, she cites a provision of the American Convention on Human Rights (Article 13(4)), which specifically discusses "the moral protection of childhood and adolescence" -- terms that do not appear in Article 17(e) of the Convention on the Rights of the Child. However, she reports that the latter portion of her argument, that the child's rights in the area should be determined by the child, is not supported by the decision of the European Court of Human Rights in the case of Handyside v. United Kingdom, Judgment of the European Court of Human Rights, 7 December 1976, series A, no. 24. Van Bueren comments that the Court "appeared to conceptualize the issues as the protection of children's welfare rather than their rights" (above, at 135) -- a conception with which these authors would completely agree in terms of the drafting of Article 17(e) of this Convention on the Rights 
of the Child.

FN28. This Article is only given a very brief mention in the discussion of protection rights in LeBlanc, above, note 2 at 124 .

FN29. Prohibitions on the abduction, sale or trafficking in children (Article 35), sexual exploitation or abuse of children (Article 34), involving children in the drug trade (Article 33), economic exploitation or poor working conditions (Article 32). LeBlanc, above, note 2 at 124, indicates that Article 36 was meant to address "other forms of exploitation" than social or economic. In discussing Article 36, Van Bueren, above, note 3 at 284, focuses on the history of the article, which originally was framed in terms of "social exploitation" -- a term appearing in the International Covenant on Economic, Social and Cultural Rights and connoting such problems as those faced by abandoned and street children. Perhaps blinkered by this historical focus, Van Bueren misses the opportunity to argue that this Article appears to be broad enough to encompass moral exploitation. To these authors, this Article seems better able to bear that interpretation than the drafting of Article 17(e) in which Van Bueren argued that morality was included; see above.

FN30. There are 686 different library systems reported as existing across Canada by the National Library of Canada. See http://www.nlc-bnc.ca/index-e.html.

FN31. Margaret Ann Wilkinson, "Not Really Unloved or Unwanted" (1983) 40 Can. Library J. 365-370.

FN32. Lois Bewley, "Public Library Legislation in Canada: A Review and Evaluation, (Occasional Paper no. 26)" (Dalhousie University Libraries and Dalhousie School of Library Service: Halifax, N.S., 1971) at 7.

FN33. Wilkinson, above, note 31 at 365.

FN34. British Columbia Library Act, R.S.B.C. 1996, c. 264, Alberta Libraries Act, R.S.A. 2000, c. L-11, Saskatchewan Public Libraries Act, S.S. 1996, P-39.2, Manitoba Public Libraries Act, R.S.M. 1987, P200, Ontario Public Libraries Act, R.S.O. 1990, P.44, Nova Scotia Libraries Act, R.S.N.S. 1989, c. 254, New Brunswick Public Libraries Act, R.S.N.B. 1973, c. N-7.01, Newfoundland and Labrador Public Libraries Act, R.S.N. 1990, c. P-40, Prince Edward Island Public Libraries Act, R.S.P.E.I. 1988, c. P-31.1, Northwest Territories Library Act, R.S.N.W.T. 1988 c. L-7, Yukon Territories Public Libraries Act, S.Y. 1987, c. 30. (All statutes as amended.) The definition of "Minister" under the Public Libraries Act for Prince Edward Island has been changed as recently as 2000 from the Minister of Education to the Minister of Community and Cultural Affairs (see S.P.E.I. 2000, c. 5, s. 3). On the other hand, it would appear that in Nova Scotia, the portfolio for public libraries, which had, until 2000, been held by the Minister of the combined portfolio of Education and Culture, is now located in the department known simply as the Department of Education. Also note that the responsibility for public libraries in Quebec, which had appeared in the Quebec Public Libraries Act, R.S.Q. 1992, c. 65, now appears in Part 3 of An Act Respecting the Ministère de la Culture, R.S.Q. 1992, c. 65. The approach to public library service in Quebec has been thoroughly documented by Diane Mittermeyer. For example, "Quebec Public Libraries and their Municipal Environment" (1990, April) Can. Lib. J. 113-115.

FN35. "Ontario Public Library Statistics" at http:// www.gov.on.ca/MCZCR/english/culdiv/library/stats.html.

FN36. Public Libraries Act, above, note 34.

FN37. Above, note 34 . 
FN38. Above, note 34.

FN39. In studying professional regulation, Elizabeth Graddy distinguishes between licensure, which "restricts the scope of practice, making it illegal for an unlicensed person to perform the service" and certification, which "restricts the use of a particular title to individuals meeting certain requirements, but does not restrict practice": "Toward a General Theory of Occupational Regulation," (1991) 72 Soc. Sci. Q. 676 at 677-678. She examined librarians, physicians' assistants, psychologists, geologists, and landscape architects and proposed a model of the factors that influence governments to regulate a profession. Table 1 shows that the number of American states that regulated librarians (presumably certification regulation, rather than licensure, which doctors and lawyers virtually universally enjoy) increased from 13 in 1968 to 23 in 1980 (at 684). Despite this increase in American regulation, Graddy concluded that "[a]rguments for regulating librarians are the least compelling [of the five examined]; there is no significant information asymmetry and thus no consumer or public interest rationale in regulation" (at 685). This conclusion, however, was dependent upon her findings that there was little variation in the provision of service from librarian to librarian, that little skill was required to evaluate the services of the librarian, and that there was a good deal of contact between librarians and patrons! There is evidence to challenge the first two findings and, as to the third, it would seem an indictment of other professions, rather than a bar to professional status for librarianship, that the professional and the client are in close contact!

FN40. The only province in Canada with statutory recognition of professional librarians is Quebec: An Act to Incorporate the Corporation of Professional Librarians of Quebéc or Loi constituant la Corporation des Bibiothécaires Professionnels du Quebéc, 1969, c. 105. The most conspicuous attempt to begin the process toward such professional recognition in the common law provinces was the Ontario statute The Institute of Professional Librarians of Ontario Act, 1962-63, S.O. 1962-63, c. 182, amended by The Institute of Professional Librarians Act, 1976, S.O. 1976, c. 96. Although the organization whose designation it protects has been dissolved since the 1970s, these private members bills still languish on the books.

FN41. A number of its first conventions were held in Canada: in Ottawa in 1912, in Montreal in 1900 and 1934, and in Toronto in 1927. Elizabeth Hulse, The Morton Years: The Canadian Library Association 1946-1971. (Toronto: Ex Libris Association, 1995) at 1.

FN42. This membership far outstrips more recent associations of information intermediaries such as the American Records Managers Association, which was founded in 1955 and has over 9,000 members, or the American Society for Information Science, which was founded in 1937 and has over 4,000 members. Only the Association for Computing Machinery, founded in 1942, boasts more members than the ALA, roughly 75,000; however, that membership is not made up strictly of information intermediaries. There are 952 personal international members and 276 organization international members in the ALA. The ALA does not further break down its figures for international members, although it has a breakdown by state for American members. However, the experience of the authors indicates that the vast majority of these international members are in fact Canadian.

FN43. There is a French language parallel association in Canada, ASTED [Association pour l'Avancement des Sciences et des Techniques de la Documentation] -- see The Morton Years, above, note 41 at 73-76, for a history of the division between the francophone and anglophone library organizations at the national level.

FN44. See Hulse, above, note 41.

FN45. See The Ontario Library Association: An Historical Sketch 1900-1925 (Toronto: University of Toronto Press, 1926). 
FN46. It claims to be the largest library association in Canada, as well as the oldest (see http://www.ola.amlibs.ca/home.html), but the CLA membership figures quoted below would suggest otherwise. Certainly it is the oldest: the British Columbia Library Association was founded in 1911, the Saskatchewan Library Association in 1914, the Manitoba Library Association in 1936, the Quebec Library Association in 1943, the Library Association of Alberta in 1955, and the Atlantic Provinces Library Association in 1956.

FN47. Such codes are one of the hallmarks of a profession. Russell Bowden, for example, lists a "code of conduct" as the eighth necessary professional responsibility: see "Professional Responsibilities of Librarians and Information Workers," (1994) 20(2) IFLA Journal 120 at 127 . None of the codes of the library associations discussed herein has any effective sanction available for breach.

FN48. John C. Swan, "Librarianship is Censorship" 104 Library J. 2040 at 2043.

FN49. The combined membership of the CLA, the OLA, and the "international members" of the ALA is about 9,000 people and institutions. These memberships can represent people and institutions from across Canada, of course -- but there is probably a concentration of memberships in Ontario. These kinds of numbers may be juxtaposed against the total number of "librarians" reported as currently working in Ontario by the Ontario Job Futures database: 4,300. See http://www.on.hdrc-drhc.gc.ca.

FN50. Richard Ellis, "Responsible Practice: A Review of CLA's Code of Ethics" (September 1994) Feliciter 40 at 45. The CLA Code of Ethics can be found at http://www.cla.ca/about/ethics.htm. The Statement on Intellectual Freedom can be found at http://www.cla.ca/about/intfreed.htm.

FN51. (July/August 1995) American Libraries 673.

FN52. This statement was initially adopted in 1948, with subsequent amendments in 1961, 1967 and 1980 : www.ala.org.

FN53. Of course, it may be noted that no right of intellectual freedom or freedom to read is actually articulated per se in the Charter.

FN54. Approved 25 March 1999. See http://www.ifla.org/V/press/pr990326.htm.

FN55. At the November 7, 1998 Annual General Meeting; see http:// www.ola.amlibs.ca/agm98res.html.

FN56. Adopted June 30 1972, amended July 1, 1981 and July 3, $1991 . \quad$ See http://www.ala.org/alaorg/oif/free_min.html.

FN57. ALA Manual of Organization 2000-2001 (Chicago: ALA, 2000) at 43.

FN58. The Manual passage is also unfortunate in its emphasis on "parents -- and only parents" whereas the preceding section from the Statement refers, more appropriately, to both parents and legal guardians.

FN59. Ann K. Symons and Charles Harmon, in Protecting the Right to Read: a how-to-do-it Manual for School and Public Librarians (New York: Neal-Schuman Publishers, 1995), neatly avoid the ambiguities and uncertainties through deft editing in their interpretation of the ALA position and make it clear that parents are to exercise their rights directly in communication with their own children and the librarians are to respond to every patron in a similar fashion, whether child or adult. 
FN60. Above, note 57.

FN61. Van Bueren, above, note 3 at 133.

FN62. Baker v. Canada (Minister of Citizenship \& Immigration), 174 D.L.R. (4th) 193, [1999] 2 S.C.R. 817, 1999 CarswellNat 1124, 1999 CarswellNat 1125 (S.C.C.) [hereinafter Baker]; see Mme Justice L'Heureux-Dubé at para. 69. See also Mr. Justice Iacobucci at para. 80.

FN63. Mme Justice L'Heureux-Dubé, ibid. at para. 69.

FN64. Mme Justice L'Heureux-Dubé, above, note 62 at para. 70.

FN65. See the judgment of Mr. Justice Iacobucci, above, note 62 at para. 79.

FN66. Mme Justice L'Heureux-Dubé, above, note 62 at para. 71.

FN67. Part I of the Constitution Act, 1982, being Schedule B to the Canada Act 1982 (U.K.) 1982, c. 11 [hereinafter "the Charter"].

FN68. McKinney v. University of Guelph (1986), 57 O.R. (2d) 1, 22 Admin.L.R. 29, 32 D.L.R. (4th) 65, 1986 CarswellOnt 850 (Ont. H.C.); affirmed (1987), 63 O.R. (2d) 1, 29 Admin. L.R. 227, 46 D.L.R. (4th) 193, 1987 CarswellOnt 951 (Ont. C.A.); leave to appeal to the S.C.C. granted (1988), 46 D.L.R. (4th) 193n (S.C.C.); affirmed [1999] 3 S.C.R. 229, 1990 CarswellOnt 1019F, 1990 CarswellOnt 1019 (S.C.C.).

FN69. Dagenais v. Canadian Broadcasting Corp., [1994] 3 S.C.R. 835, 1994 CarswellOnt 112, 1994 Carswel1Ont 1168 (S.C.C.) and Hill v. Church of Scientology of Toronto, [1995] 2 S.C.R. 1130, 1995 CarswellOnt 396, 1995 CarswellOnt 534 (S.C.C.).

FN70. This right is briefly touched upon in James R.P. Ogloff, "Children's Intellectual Rights in Canada: A Comparative Constitutional Approach" (1989) 68 Neb. L. Rev. 349 at 362-363.

FN71. Freedom of conscience and religion in the Canadian Charter of Rights and Freedoms is protected in section 2(a).

FN72. See Article 13(1) set out above.

FN73. Luscher v. Deputy Minister of National Revenue (Customs \& Excise) , [1985] 1 F.C. 85, 1985 CarswellNat 196, 1985 CarswellNat 612 (Fed. C.A.) where Mr. Justice Hugessen, speaking for the Court, wrote at paras. 5 and 8 :

The appellant does not argue that Parliament could not prohibit or regulate the importation of material of this sort, commonly described as "smut", but rather that the prohibition as drawn in the legislation is invalid. I am in agreement with that submission. . That a prohibition whose first object is [the importation of] "books" is prima facie an infringement of the freedoms protected by paragraph 2(b) appears to me to be a proposition not requiring demonstration.

FN74. In other words, there may be limitations that could be defended in Canada as reasonably and demonstrably justified in a free and democratic society, which would still fall beyond the exceptions to the rights to information permitted under the Convention. Query whether limitations that are grounded in the exceptions per- 
mitted under the Convention will ever be considered not reasonably and demonstrably justified in a free and democratic society under the Charter.

FN75. Adapting the Canadian s. 1 Charter formula to the factors listed in the Convention would result in the following balancing exercise: if a government's "guidelines for the protection of the child from information and material injurious to his or her well-being" (Convention, Article 17(e)) were found to emphasize the primary responsibility of parents in raising their children (Convention, Article 18(1)) over the child's information rights in a way that was "reasonably and demonstrably justified in a free and democratic society" (Charter, s. 1), the parents' responsibility under the guidelines would be considered as a legitimate limitation on the child's own information rights and the government's guidelines would be considered legitimate under the Charter.

FN76. See the discussion above.

FN77. "Libraries should resist all efforts to limit the exercise of these responsibilities ["to guarantee and facilitate access to all expressions of knowledge and intellectual activity"] while recognizing the right of criticism by individuals and groups." See http://www.cla.ca/about/intfreed.htm.

FN78. Ontario Library Association Statement on the Intellectual Rights of the Individual: http://www.accessola.com/action/positions/intellectual_rights.html.

FN79. There does not seem to be any recognition of the reality that ownership of intellectual property rights necessarily includes control that can censor. See David Vaver, "Some Agnostic Observations on Intellectual Property" (1991) 6 I.P.J. 125; see also Margaret Ann Wilkinson, "Anticipating the Impact of Intellectual Property Protections" 21 Can. J. of Information \& Library Sci. 23.

FN80. B. (R.) v. Children's Aid Society of Metropolitan Toronto (1994), [1995] 1 S.C.R. 315, 1995 CarswellOnt 105, 1995 CarswellOnt 515, 9 R.F.L. (4th) 157 (S.C.C.).

FN81. Ibid., per Mr. Justice La Forest at para. 71.

FN82. On the result of the main action all nine concurred, although Mme. Justice L'Heureux-Dubé dissented on the cross-appeal.

FN83. Section 7 states "Everyone has the right to life, liberty and security of the person and the right not to be deprived thereof except in accordance with the principles of fundamental justice."

FN84. Per Mr. Justice La Forest at para. 85.

FN85. Per Mr. Justice La Forest at para. 87. In an addendum to his judgment, written after he had read the judgment of Mr. Justices Iacobucci and Major, he indicated that his emphasis on the rights of the parents in the case was shaped by the circumstances of the case, which raised the question whether the parents' rights were violated. "In such a case, the parent's rights must, under s. 1, be balanced against the interests of others in a free and democratic society -- in this particular case, the right of their child. . If a situation arose where it was alleged that the child's right was violated, other rights might be raised as reasonable limits." (at para. 117).

FN86. Per Mr. Justice Lamer at para. 1. Mr. Justice Sopinka dissented on this same issue, but on other, more limited grounds. 
FN87. Per Mr. Justice Lamer at 331-333 [S.C.R.], citing R. v. Jones , [1986] 2 S.C.R. 284, 1986 CarswellAlta 181, 1986 CarswellAlta 716 (S.C.C.).

FN88. Per Mr. Justices Iacobucci and Major, at 433 [S.C.R.].

FN89. Per Mr. Justices Iacobucci and Major, at 434 [S.C.R.]. It may be noted that their reluctance stemmed at least in part from the fact ". this court has not had the benefit of full argument on the appropriate contours between the rights protected by s. 7 and the freedoms covered by s. 2" (at para. 222).

FN90. Per Mr. Justices Iacobucci and Major at para. 221.

FN91. Marilyn Gell Mason, "Sex, Kids, and the Public Library," (1997) 28(6) American Libraries 104-106 at 104.

FN92. Ann K. Symons and Charles Harmon, Protecting the Right to Read: A How-to-do-it manual for school and public librarians (New York: Neal-Schuman, 1995) at 11.

FN93. Symons and Harmon, ibid. at 11.

FN94. Mary K. Chelton, "Issues in Youth Access to Library Services; A commentary on professional attitudes and practices" (1985) 14(1) School Library Media Q. 21 at 21. Chelton says the "ALA is quite clear" on this issue and quotes the ALA "Free Access to Minors" interpretation of the Library Bill of Rights as providing "Libraries . should bear in mind that they do not serve in loco parentis." It may be noted that that language does not appear in the current version of that ALA document. Unfortunately, while the article provides many interesting examples of practices in libraries that can have a discriminatory impact on young patrons, Chelton does not explore the overriding access issue that she has identified.

FN95. Kay E. Vandergrift, "Are Children and Teenagers Second-Class Users?" (1989) 33(4) Library Resources and Technical Services 393 at 396-397.

FN96. Edmonton (City) Library Board v. Morrill (1989), 58 D.L.R. (4th) 354, 1989 CarswellAlta 286 (Alta. Q.B.) at para. 1.

FN97. Vandergrift, above, note 95 at 396.

FN98. Frances M. McDonald, "Information Access for Youth: Issues and Concerns" (1988) 37(1) Library Trends 28 at 29.

FN99. Charles Harmon and Ann K. Symons, ""But We're Family Friendly Already": How to Respond to the Challenge" (1996) 27 American Libraries 60-64.

FN100. See Carolyn Caywood, "Parents, Kids, Librarians: Can this Relationship be Saved?" (1999) 30(6) American Libraries 74.

FN101. For example, in London, Ontario, the London Public Library has installed such software on at least one machine in the children's section of the main library, which has provoked some debate in the daily newspaper. See Joe Paraskevas, "Police Board, Library Clash over Internet" London Free Press (7 August 1999) A1; Brodie Fenlon, "Library Net Filters Oppose: Privacy Expert says Information Access should be Provided, not Preven- 
ted" London Free Press (24 October 1999) A3; Ross Daily, "Censorship Not a Reasonable Choice" London Free Press (14 August 1999) D3. One of the most interesting aspects of the debate is the revelation that the Police Services Board had encouraged installing such software on all networked machines in the library system that were intended for access by children (Paraskevas, ibid.).

FN102. Janet Hildebrand, "Is Privacy Reserved for Adults? Children's Rights at the Public Library" (1991) 37(1) School Library J. 21.

FN103. Hildebrand, ibid. at 22, apparently quoting directly from the legal opinion received from the County counsel by the Contra Costa County Library. This library is located in California and the opinion was therefore based on the law of that state. Hildebrand recognizes that, "state laws and court history vary widely from state to state" (at 22), but comes to the rather curious conclusion that, in consequence, "the local interpretation can differ within the same state or county" (at 22). It seems that that conclusion must be mistaken: the law will not vary within the same territorial jurisdiction (presumably in this context, within the same state). The facts however, may well vary slightly from library to library even within the same jurisdiction, which would indeed make her advice that, "Libraries must therefore work with their own legal counsel from the beginning" (ibid.) very sound. The law will vary between jurisdictions: from state to state or between the American states and the Canadian provinces

FN104. Hildebrand, above, note 102 at 23.

FN105. Hildebrand, above, note 102 at 24.

FN106. Hildebrand, above, note 102 at 24.

FN107. Hildebrand, above, note 102 at 25, referring to attorney Roger Funk's presentation at a California Library Association conference in November 1990.

FN108. Deborah L. Vroman, "To See or Not to See: A study of Video Collections Censorship in American Public Libraries" (1995) 35 R.Q. 37 at 39, quotes from James G. Scholtz, Developing and Maintaining Video Collections in Libraries (Santa Barbara, CA: ABC-Clio, 1989) at 157, as follows:

Most states have enacted access-to-minors statutes, and some prohibit libraries from loaning certain motion pictures and videos to minors. However, the great majority of states specifically exempt libraries and other educational institutions from this law.

FN109. Report on the Powers of the Ontario Film Review Board (Toronto: Queen's Printer, 1992) at 75.

FN110. See, respectively, the following: Amusements Act, Revised Statutes of Alberta 2000, c. A-40, as amended; The Amusements Act, Revised Statutes of Manitoba 1987, c. A70, as amended; Film and Video Act, Revised Statutes of New Brunswick 1988, c. F-10.1, as amended; Theatres and Amusements Act, Revised Statutes of Nova Scotia 1989, c. 466, as amended; Theatres Act, Revised Statutes of Ontario 1990, c. T.6, as amended; Film and Video Classification Act, Statutes of Saskatchewan 1984-85-86, c. F-13.2, as amended, esp. s. 13.

FN111. Revised Statutes of British Columbia 1996, c. 314, as amended.

FN112. Revised Statutes of Quebec, c. C-18.1. 
(Publication page references are not available for this document.)

FN113. See "Abuse Film Banned in Maritimes" London Free Press (27 February 1997) C3.

FN114. Ibid.

FN115. Ibid.

FN116. Prince Edward Island has a curiously drafted statute about film censorship that seems to have a very limited application on its face: see Films Act, Revised Statutes of Prince Edward Island 1988, c. F-8. Even for the films that it appears on its face to cover, the statute specifically adopts the decisions of the Nova Scotia film board (see s. 1(a)). In fact, the Nova Scotia board is the film board for all Prince Edward Island films, as well as for New Brunswick (by regulation) and for Newfoundland (de facto). See http:// www.media-awareness.ca/eng/indus/filmuid/nfldfilm.htm. See the Ontario Law Reform Commission Report at 76-77.

FN117. Vroman, above, note 108.

FN118. "Statement on Labelling" at http:// www.ala.org/alaorg/oif/labeling.html.

FN119. Vroman, above, note 108 at 39. It may be noted that Vroman's quote from the Policy leaves out the material provision that MPAA ratings may be displayed, not only if they are included on the tape or in the packaging, but also "if they appear in review sources or reference works included in the library's collection." (See text of Policy in the text below.)

FN120. Intellectual Freedom Manual, 5th ed. (1996) 20 at 21-22.

FN121. Ibid. at 21.

FN122. Samantha Brennan and Robert Noggle argue that there are three basic moral positions that can be taken with respect to children's rights: "The equal considerations thesis: Children are entitled to the same moral consideration as adults. The unequal treatment thesis: Children -- at least at certain ages -- can be legitimately prevented from doing certain things that it would be illegitimate to prevent adults from doing . [and] The limited parental rights thesis: Parents can legitimately exercise limited but significant discretion in raising children. (At pp. 2-5.) Brennan and Noggle reconcile the first two positions by arguing that the second is really about roledependent rights, which remain consistent, whether or not they are able to be exercised, with being given equal moral consideration (under the first position) (at pp. 7-8). They claim the parental right is best understood as a "threshold right," which can be overridden by other rights in certain circumstances (p. 9) and are "stewardship rights" (p. 13). They argue that "[e]ven if [the rights of the child] must be overridden in a particular case, they do not vanish completely" (p. 19). They argue that understanding all three rights in these terms means that they can co-exist (pp. 12 and 15) and that apparent internal conflicts between the three are thus resolved (p. 2). They argue that their approach is preferable to both the best interest test" and the "clear and present danger standard," which currently compete for implementation in our law (pp. 20-21). See "The Moral Status of Children: Children's Rights, Parents' Rights, and Family Justice" (1997) 23 Soc. Theory \& Practice 1.

\section{END OF DOCUMENT}

